\title{
Mother Tongue Education: Lessons for Botswana
}

\author{
Lone E. Ketsitlile, Uju C. Ukwuoma \\ Botswana International University of Science and Technology, Palapye, Botswana
}

\begin{abstract}
Mother tongue education is a cause for concern in many places of the world, including Botswana. This paper paints a picture of what is happening in Botswana with regard to mother tongue education and other places in the world and what Botswana can emulate, adopt, or adapt. This is important to enable Botswana to set the ball rolling in the right direction regarding the teaching of minority languages in schools and their inclusion in socio-economic and political spheres of life. The Botswana Government recognizes the existence of mother tongue languages and agrees that they should be taught in schools, yet mother tongue education has become a mere talk and only Setswana (national language) and English (official language) are taught in schools. We advocate and reiterate the urgent need for a comprehensive language reform in education policy in Botswana to cater for diversity and multiculturalism.
\end{abstract}

Keywords: mother tongue education, language, identity, linguistic human rights, integration and assimilation

\section{Introduction}

When Botswana gained independence from British colonial rule in 1966, English became the medium of instruction in schools, starting from Standard 1 (Grade 1) (Nyati-Ramahobo, 2004). At independence, teachers were allowed to code-switch between Setswana and English at the lower grades to facilitate student understanding (National Commission on Education [NCE], 1977). A shift occurred with the NCE (1993) which reduced the use of the number of years for Setswana as medium of instruction to one. The NCE regarded a child's first language as a threat to second language acquisition (English) which is the language of prestige in Botswana. Although the commission also recommended the use of minority languages at pre-primary education, this was rejected by the Botswana Government. According to Nyati-Ramahobo (1991), "The language planning processes in Botswana are influenced by an orientation which views language diversity as a problem, a reversal or negation of democratic gains, a threat to unity, social harmony and to development" (p. 201).

According to Nyati-Ramahobo (2004), the Botswana Government opposes the use of minority languages in government, education, politics, and business under the guise of national unity, to the advantage of Setswana, which is marketed as a unifying language in Botswana. We concur with Mooko (2006) that this "unity" disregards the importance of cultural diversity in Botswana. The Revised National Policy on Education (Botswana Government, 1994) reversed the decisions of NCE (1993) and recommended that Setswana be used for instruction in the first three years of a child's schooling and English throughout.

The language policy of Botswana has in many ways caused the promotion of English and Setswana and

Lone E. Ketsitlile, Ph.D., professor, Department of Technical Writing and Academic Literacy, Botswana International University of Science and Technology. Email: ketsitlilel@biust.ac.bw.

Uju C. Ukwuoma, Ph.D., senior lecturer, Department of Technical Writing and Academic Literacy, Botswana International University of Science and Technology. Email: ukwuomac@biust.ac.bw; ujucukwuoma@aol.com. 
relegated indigenous/marginalized languages to the background. According to the Revised National Policy on Education (Government of Botswana, 1994, p. 1), English and Setswana are the two languages of instruction in school. English is taught from Standard 3. Without doubt, language plays a major role in San formal education frustrations. The San and other minorities in Botswana are forced to learn in languages that are foreign to them: English and Setswana. For the San children, Setswana and English are usually second and third languages. In schools, the San are disadvantaged, especially upon initial entry as they often do not understand the language of instruction (Ketsitlile, 2011, as cited in Julius, 2014; Wagner, 2006). What makes the problem worse for the San children is that the gateway examinations at primary and secondary schooling are in English. These examinations are very important, because entry into college and university depends on them. Ron, one of the San tribal elders, said the following during an interview with Hays, a researcher: "Children normally start with the very difficult two official languages other than starting with the mother tongue languages. That makes it very difficult for some children to capture school at the same levels as the young Setswana speaker..." (Hays, 2002, p. 93).

Numerous studies carried out in Botswana at the advent of San formal education attest to the fact that these children face insurmountable problems in the road to formal education, especially as a result of being compelled to learn in Setswana and English (Biesele \& Hitchcock, 2000; Chebanne, 2014; Hays, 2002; Ketsitlile, 2014; Mazonde, 2002; Magogwe, 2007; Nyati-Ramahobo, 1999).

In order to clarify for the reader the language barriers experienced by San children in Botswana, we draw upon a study carried out in 1995 by Pridmore in Ghanzi district in Western Botswana. The study involved two sets of children: primary school children "little teachers" and pre-school going children. The "little teachers" role was to transfer health messages to the pre-school children in Setswana and all this was done under the supervision of adult teachers. The pre-school going children were tested before and after the intervention and in both sets of children, it was noted that no health messages were learnt. This further corroborates research that attests to the fact that children learn better and faster in their mother tongue (Kembo, 2000). Little has changed with regards to mother tongue literacy in Botswana since the Pridmore study (Chebanne, 2014). According to Magogwe (2007), all school going children in Botswana find Setswana difficult, especially marginalized children.

\section{Cultural Loss}

The language policy in Botswana has also resulted in a loss of culture for the San and other minority peoples. Language problems have created what we call a vacuum in their home-school connections. At school, they have to learn and speak English and Setswana, which also includes acquiring the two cultures, to some extent. At home, they have to speak their San language(s). This has the dire effect that children become caught in two cultures and do not, in our opinion, excel in either one. We concur with Nyati-Ramahobo (2002) that language and culture cannot be separated. She speaks for others when she says that pruning and hiding some of these diverse cultures and languages is impoverishing Botswana's rich multiculturalism. Clearly, a loss of language means a loss of identity (Gatsha, 2005).

The Botswana Government states in Vision 2016 (Botswana Government, 1998) that:

Botswana's wealth of languages and cultural traditions will be recognized, supported and strengthened in the education system. No one will be disadvantaged in the education system as a result of a mother tongue that differs from the country's two official languages. (p. 5) 
This is a welcome policy but, still, minority languages have not been incorporated into the curriculum despite the fact that there are about 20 minority languages, according to Andersson and Janson (1997). The San are classified into nine main ethnic groups, and they speak about 23 languages and dialects. The non-San are ethnic Bantu groups.

Language experts in Africa have for a long time campaigned for the use of mother tongue in the education system. According to many researchers, there are ample benefits to be accrued from all these (Ketsitlile, 2009; Mokibelo \& Moumakwa, 2006; Mooko, 2006; Nyati-Ramahobo, 1999). Firstly, scholars the world over are in tandem that children learn better in their mother tongue, especially in the primary school stage. Secondly, language is very much bound with culture. Thirdly:

Literacy programs become successful when reading materials contain information the learners can relate to. They learn to read and write by doing so on issues that are familiar to their cultural experiences. This enhances their self-esteem, which is one of the determinants of academic achievement. (Nyati-Ramahobo, 1998, p. 9)

Stroud (2003) is of the view that, there is a need for rethinking the purpose, function, and methodology of teaching languages in developing African contexts for optimal benefit for the people of Africa.

Nyati-Ramahobo (1998) wrote that while Batswana have Setswana as a national language, they also speak other languages that represent cultural backgrounds that are both similar and different. She speaks for others when she says that pruning and hiding some of these diverse cultures and languages is impoverishing our potentially rich culture. A loss of language means a loss of identity (Gatsha, 2005, p. 1). The thinking among the most senior policy-makers in Botswana is that the time has come for officially recognizing the languages of the so-called minority tribes (Mazonde, 2002). Yet progress is slow, one might say that they are at an embryonic stage. NgugiWaThiog'o captures the need for mother tongue literacy well by saying, "African poetry, true African poetry, is never written in any language outside the African's mother tongue-words cannot flow from the soul if written in any language apart from ones mother tongue" (Gatsha, 2005, p. 5).

There is an urgent need for a shift in the minority language issues as multilingualism is an important means of bringing about social and political transformations in developing contexts - a site of struggle, to use a well-worn metaphor ... multilingual practices are tied into the articulation of new discourses on identity, civil rights, and issues of social class for marginalized individuals (Stroud, 2003, p. 21). This concurs well with Ukwuoma (2014, p. 5) that "thus, the use of the mother tongue as well as familiar languages provides learners, particularly children, with security, bonding and a sense of community, which are pivotal in acquiring literacy and academic competence in other languages" (Cook, 2010; United Nations Educational, Scientific, and Cultural Organization [UNESCO], 2003; as cited in Ukwuoma, 2014).

The lack of diversity and multicultural education in Botswana is disadvantaging minority populations, especially the San. For example, although San children have been going to school in their respective countries (Botswana, South Africa, Namibia, and Zimbabwe) about 30 years ago, Le Roux (1999) reported that only a few of them have made it to tertiary education. A study carried out by Le Roux among the San of Botswana reveals that education for the San is still a problem although acculturation is taking place among the San all over Southern Africa. Below is information from Chebanne and Monaka (2005) reporting school attendance among the !Xo (San) of the Kalahari Desert. 
Table 1

Percentage of!Xo (San) Students in School

\begin{tabular}{lll}
\hline Standard & Percentage of !Xo students in school & \\
\hline 1 & $80 \%$ & $\begin{array}{l}\text { The first two years of shock and disillusionment and the hostility of } \\
\text { teachers who have no knowledge of the !Xo language or the experience of } \\
\text { dealing with the ethnic group as well as no means to help them to adopt. } \\
\text { Teachers ask other students to interpret information to the !Xo students. }\end{array}$ \\
2 & $60 \%$ & \\
\hline 3 & $20 \%$ & $\begin{array}{l}\text { Those students who remain are acculturalized and refuse to come back to } \\
\text { speak !Xo. But only 3\% of these make to Community Junior Secondary } \\
4\end{array}$ \\
5 & $20 \%$ & School. \\
6 & $15 \%$ & \\
7 & $10 \%$ & \\
\hline
\end{tabular}

Table 2 compares the performance of San and non-San students in Botswana. Clearly, non-San students perform much better than their San counterparts (Odetei, 1991, as cited in Chebanne \& Monaka, 2005).

Table 2

Student Performance in Botswana: San/Non-San

\begin{tabular}{lllllll}
\hline & District & Grade A & Grade B & Grade C & Grade D & Type of area \\
\hline 1 & Kweneng & 16.7 & 23.7 & 25.6 & 44.0 & \\
2 & South East & 14.3 & 31.0 & 19.8 & 34.9 & Mainly Setswana speakers \\
3 & Kgatleng & 8.2 & 22.4 & 30.9 & 39.7 & \\
\hline 4 & Kgalagadi & 3.9 & 18.9 & 33.7 & 43.5 & \\
5 & Ghanzi & 5.9 & 19.1 & 36.8 & 38.2 & Mainly minority speakers \\
6 & North West & 4.0 & 18.3 & 34.6 & 43.1 & \\
\hline
\end{tabular}

Note. Source: Primary School Leaving Examinations (Botswana Government, 1991).

Batibo (2004) also expressed the same observations in his study. The Botswana Government implemented a recommendation that pupils were entitled to 10 years of basic schooling, from Standard 1 (Grade 1) through Form 3 (Junior Secondary School). As a result, the last primary school examination results that are available are the 1991 results.

\section{Is Language a Weapon or Tool?}

Language has been blamed as the number one weapon used by mainstream societies to subjugate those in the minority. That language is not only important for communication, it is also a carrier of a people's culture and a badge of identity, is without doubt. Many indigenous peoples are prohibited in today's "democratic" world to learn and speak the necessary mother tongue language(s) at school. For example, in Tanzania, it is illegal for the Hadzabe peoples to speak any other language than Swahili at school (Kaare, 1994). In Kenya, what is surprising is that indigenous peoples are not allowed to converse in their mother tongue in school, although it is similar to Swahili (Commeyras \& Inyenga, 2007). A Hualapi boy (native American) captures well the negative impact of language repression by saying:

I do not feel complete ... Sometimes, I feel apart from my peers, the ones that are my age that do speak, and they all know that I do not speak ... Coming to terms with my identity and seeing my deficiencies, I could tell the kids today that if you do not know your language, you will feel (as I do).

On the other hand, some minorities in the world, such as the Norwich and the Finns in Sweden, are facing 
positive changes in their language revitalisation, religion, traditional economy, and others (Saugestad, 2004; Zips-Mairitsch, 2013).

Clearly, ignoring minority languages is one long battle for most people the world over and has more disadvantages than advantages. For example, research shows that students instructed in their mother tongue do much better than if they are instructed first in a foreign language (Cummins, 2009; Le Roux, 1999; Ketsitlile, 2009 ) and this is also good for their second and third language acquisition. Hawaii indigenous peoples perform much better in school as a result of the total immersion followed in schools. This is in direct opposition to many African states which inherited a foreign language policy, disregarding the cultural and political problems resulting (Mateene, 1980, as cited in Mule, 1999). This tells of a cultural and mental subjugation by a power that is still very much in control today in many parts of the world. Unfortunately, it is the indigenous and minority peoples who are suffering more as in a lot of cases, English is a third language for them, for example, the San of Namibia, the Tuareg of the Sahara, and the Chagga of Tanzania. These children face insurmountable problems in schools, such as high school dropout rate. Research also points to the fact that many school dropouts cannot read in their mother tongue, or in an international language, such as English (Cummins, 2009; Muthwii, 2004). We concur with Muthwii (2002, as cited in Muthwii, 2004) that there is a misconception that English comes "naturally" (p. 4) for children from multilingual backgrounds.

However, research continues to point to the fact that cognitive development occurs effectively only through a language that the learner knows very well, for example, a mother tongue or a first language ("I understand this to mean full understanding of a language in all socio-linguistic and cultural domains") as explained by the father of sociolinguistics, Dell Hymes (1964). In addition, for the learners to understand, organize, and select information, it is crucial that they are proficient in the first language. Africa needs to radically rethink the place of indigenous languages of education for a successful future in all spheres of life. It is worrying that the clamored language of prestige (English) is not being used effectively in professional and administrative settings. In Nigeria, for example, out of the 33\% of Nigerians who are reported to be literate in English, Muthwii (2004) reported that only 15\% of those can use English effectively. As a result, students who perform poorly in English or speak languages other than English, particularly at institutions of higher learning, are classified as academic low achievers because proficiency in the English language is thought to predict academic achievement in Nigeria (Fakeye \& Ogunsiji, 2009, as cited in Ukwuoma, 2014).

According to Ukwuoma (2014), Nigerian Creole, the Sapele, and Warri variants of what is referred to as Nigerian pidgin is an example of a language often disregarded by lecturers.

There is an entrenched belief all over the world that minority languages are expensive to develop and that they are impossible to use for technological and economic development. We feel that it is much more expensive to ignore minority languages. Africa needs to emulate the Asian countries, such as Japan and China, whose economies are doing exceptionally well partly because they take pride in their languages.

\section{Linguistic Human Rights}

Haboud (2009) is of the view that:

Since the Universal Declaration of Linguistic Rights in 1996, there is a tendency not only to maintain linguistic and cultural diversity worldwide, but also to ease universal access to quality education which should comprise the learning of other languages and cultures and the generation of intercultural relations. (p. 63) 
Linguistic human rights promote linguistic justice and aim to eradicate the removal of linguistic injustices throughout the world (Nyati-Ramahobo, 2005; UNESCO, 2014). When it comes to language preference, most people in the world have very little say. What is happening in most schools that minority children attend is the direct opposite of the vision that the United Nations (UN) has for indigenous and minority children worldwide. Researchers posit that linguistic human rights should be treated with the seriousness that they deserve in order to avoid flagrant violation of human rights (Rantsudu, 2014).

\section{Bilingualism/Multiculturalism}

Bilingual and multicultural programs are seen by many as panacea to the language and cultural problems faced by minority children. To illustrate this reasoning further, we invite the reader on a journey to Ecuador and Bolivia where bilingual programs are facing many challenges. In Ecuador and Bolivia, there is a conflict of beliefs in bilingual programs and how they should be run (Cotacachi, 1997). Basically, there are two opposing poles of thought: those who are for bilingual education and those parents who are against it. The proponents of bilingual education argue that it will offer their children a chance to identify with their mother tongue (Quichua) and also their children will not forget their culture. According to Haboud (2009), since the Universal Declaration of Linguistic Rights in 1996, there is a trend not only to maintain linguistic and cultural diversity worldwide, but also to ease universal access to quality education which should reflect the learning of other languages and cultures and the generation of intercultural relations. Haboud (2009) discussed the rights that minority peoples in Ecuador have to learning other languages while reinforcing their own which is very important for self-actualization, identity, rights, and power issues.

However, in some schools and districts, parents and administration officials were adamantly against bilingual education due to a number of reasons. Firstly, some parents were against it simply because the principals of some schools were against it. This is what one (principal) had to say about Quichua during an interview with a researcher, "Quichua does not have grammar: It is a poor language and not worth teaching" (Cotacachi, 1997, p. 286). Secondly, Spanish teachers in Ecuador and Bolivia campaigned against indigenous languages because they feared losing their jobs (Cotacachi, 1997). The third and probably most serious reason is that parents have to volunteer to teach the language in schools and this is not always possible given their other responsibilities. In Bolivia, issues of language status and orthography also came up.

What is clear from the Ecuadorian and Bolivian examples is that indigenous languages are still heavily stigmatized. According to Haboud (2009), there is a tendency in Ecuador to view diversity as "inexistent, or to continue regarding groups that are not part of the dominant ranks in a romantic or paternalistic way" (p. 65). A plus in the Ecuadorian education system is that from 1993, teachers were trained in the bilingual intercultural education system. They were taught both English and an indigenous language, for example, Kichwa.

We concur with Garcia (2004) that "intercultural bilingual education is a bold initiative, but as currently implemented it leaves many gaps" (p. 29). In a lot of bilingual cases that we have come across, the bilingual systems are based on Western models of education that have been directly superimposed to fit the local indigenous framework and, in our opinion, this does not always work. Aikman (1995) is right in saying that such programs are hardly successful and what is needed is a "union" between global similarities and thorough knowledge of what is taking place in a given indigenous setup. 


\section{Integration/Assimilation}

Often, it is misconstrued that by assimilating or integrating to the norms and values of dominant groups, the lives of indigenous peoples will automatically change for the better and result in improved lives for indigenous peoples (Bodley, 1988, as cited in Le Roux, 1999). In order to do so, indigenous and minority children need to fully adopt the ways and rules of formal schooling (including not learning in their languages) without question and surprisingly, some indigenous and minority parents feel that this is the only way for their children to be at par with mainstream societies and excel in today's competitive world (Aikman, 1995; Halliday, 2014). Some indigenous peoples posit that they would rather go the assimilation route than what they are currently experiencing.

However, we find this to be a catch-22 situation: If indigenous peoples opt to go the assimilation route as some reason, they will lose their languages, identities, and culture. In addition, research points to the fact that there is a gap existing between the language of the home and that of school, for many indigenous peoples of the world (White-Kalauty, 2007; Ketsitlile, 2009; 2014). Most researchers take this reasoning further by saying that examples of minority groups whose children do very well in schools indicate that it is not a direct result of cultural and linguistic differences, but other factors, such as power relations between the dominant groups and minorities that have a lot to do with school success. In most parts of the world, minority groups are the poorest, marginalized, and most abused groups of people (in our opinion), and as a result, this hinders them to succeed at school. Governments need to urgently address the disparities existing between marginalized peoples and dominant ones. One way is through the inclusion of minority languages in formal education and other spheres of life.

\section{Preservation}

Having painted the above picture of the dilemmas indigenous and minority peoples face in formal education, we do not by any means posit that they should alienate themselves from the rest of the world and "go into hiding." We concur with Le Roux (1999) that "an education with only cultural preservation as its goal would not only be unrealistic, but would leave indigenous peoples unprepared to deal with the very immediate reality of cultural contact at many levels" (p. xx). We concur with Skutnabb-Kangas, Phillipson, and Rannut (1994) and the UN who caution that indigenous peoples should be careful of cultural genocide.

The UN warns that genocide also includes "forced transfer of children to another community or group" (p. 72) which can "either be physical or psychological or both" (p. 72). Also, included in the UN's definition of genocide is forced teaching of foreign languages and lack of respect for the students' home culture and language(s). The Aborigine and Arakmbut serve as models for other indigenous peoples in the world as they were able to resist cultural genocide to a large extent and retained their identities. Aikman (1995) reported that the Arakmbut of Peru today are "hunters, gathers, and agriculturalists, but also gold-panners, university students, and carpenters. Yet, they remain distinctly Arakmbut" (p. 607) and have avoided "cultural hybridity" (Semali \& Kincheloe, 1999, p. 24).

Many of the worlds' languages are extinct and many face extinction if nothing is done to save them. Hence, language revitalization and endangerment are crucial issues in this century that need all our attention. From our reading of the book Saving Languages, the authors point to the fact that people (at the individual, community, and national levels) should really want revitalization and it should not be something that they feel is foreign and they 
cannot relate to. Well-trained teachers, finance, materials, technology and most importantly, a well-informed and willing government, all go a long way in creating successful literacy programs (Grenoble \& Whaley, 2006).

\section{Alternative/Intervention Programs to Enhance Indigenous and Minority Literacy}

In order for the indigenous and minority peoples to be heard and taken with the seriousness and respect they deserve, alternative/intervention programs are a must. Some indigenous peoples have made impressive progress in indigenizing the curriculum and making it more "indigenous friendly" by hiring teachers from their communities to teach their children their mother tongue. This is deemed necessary (Aikman, 1995) as they will also transfer the culture to the children. On the other hand, some feel that outsiders are better placed to teach their children as they are in a better position to transfer the culture of the dominant group and provide a balance between their culture and a Western one. The reader is invited to note that it is impossible to discuss all the programs that exist. For the purposes of this article, we will shed light on the ones we deem most successful and which we strongly feel Botswana will benefit greatly by emulating, adopting, or adapting. The presentation of the programs is not in any specific order.

\section{Australia}

In Australia, universities have made impressive strides in assimilating indigenous languages and knowledge into mainstream programs (Ketsitlile, Bulawa, \& Kgathi, 2013). An example is the Centre of Aboriginal Studies, an organizational context for indigenous research. The aim of the centre is to cater to the specific needs of Aboriginal people: educational, social, and cultural. Secondly, the importance of Aboriginal knowledge is acknowledged, and their identities and self-determination are re-enforced. Most importantly, Aboriginal peoples are encouraged to look inward and not outward for solutions to their literacy, language, and educational problems.

All courses and programs are controlled by Aboriginal peoples who are the "watchdogs" of the centre. The centre is headed by an Aboriginal person and Aboriginality is the deciding factor for key positions than university degree(s). The focus of the centre is on Aboriginal ways of knowing and the students work closely with Aboriginal mentors in the centre and the community. In this way, the students and the community have a sense of ownership of the curriculum, connect with true Aboriginal indigenous literacy and networking relationships are formed. Indigenous and minority peoples need to play a leading role in indigenizing the academia. They need to be "academic gatekeepers" in their communities (Mihesuan \& Wilson, 2004). This will reduce the continued devaluation of indigenous and minority knowledge by the others. We posit that there is a need to revalue minority languages in schooling and non-schooling settings. In our opinion, there is no "best" approach. What is important is what will work for a given minority group.

\section{Hawaii}

Papahana Kaiapuni (Hawaiian language immersion program) was established in 1987 as a way to address the fast disappearance of Hawaiian languages and it is said to be among the best in the world (Grenoble \& Whaley, 2006). What makes the program work is the selfless devotion of individuals to Hawaiian revitalization. In addition, the community invests time and money and Hawaiian language is used inside and outside schools, for example, during sporting activities. Setting up this immersion programs is the initiation of parents, community leaders, and teachers who felt a need to salvage their languages which were fast being replaced by 
English. Children from pre-school to Standard 3 are fully immersed in the native language and English is introduced after that. The native language is not abandoned, but continues to be studied alongside English.

Punana Leo preschools, completely modeled along the ones in New Zealand, is a total immersion program with parents paying tuition for the running of the school and teaching on a rotational basis at the school, which is administered by Aha Punana Leo, a non-profit organization. The goal of the preschools, among others, is to raise children's self-esteem and identities at an early age and inculcate a spirit of pride in their mother tongue. The Mohawk peoples follow a similar kind of immersion program as the Hawaiians and they too have been successful. At present, there is a standard orthography in Mohawk and it is currently widely spoken.

\section{Ecuador}

The Shuar Indians of Ecuador have resorted to technology to improve access of minorities to education. Television programs transmitted in minority languages bring education and culture into the comfort of their homes. This came as a result of their children performing poorly in formal schools and the subsequent high dropout rates at school. Books are written by Shuar authors and offer lessons in Shuar history and culture. According to research, this has greatly improved their academic performance and strengthened their cultural identity.

\section{Conclusion}

We believe that there is a need to revalue minority languages in schooling and non-schooling settings in Botswana. As it is evident in this article, issues of mother tongue education are a global concern and they need to be addressed with the seriousness that they deserve if we are to develop into true democratic societies. In Botswana, there is an urgent need to move towards a comprehensive language in education policy that will cater for the diversity in the country. In our opinion, there is no "best" approach. What is important is what will work for a given indigenous and minority group.

\section{References}

Aikman, S. (1995). Territory, indigenous education and cultural maintenance: The case of the Arakmbut of south-eastern Peru. Prospects, $X X V(4), 593-608$.

Andersson, L. G., \& Janson. J. (Eds.). (1997). Languages in Botswana: Language ecology in Southern Africa. Gaborone: Longman Botswana.

Batibo, H. (2004). Marginalisation through educational medium: The case of the linguistically disadvantaged groups in Botswana and Tanzania (LAUD 2004 Paper No. 163, Universidad Duisburg-Essen).

Biesele, M., \& Hitcock, R. K. (2000). Ju/hoan language education in Namibia and its relevance for minority language education in Botswana. Retrieved October 4, 2007, from http://www.kalaharipeoples.org/documents/Bies-Hitch.pdf

Botswana Government. (1991). Ministry of Education. Gaborone: Government Printer.

Botswana Government. (1994). The revised national policy on education. Gaborone: Government Printer.

Botswana Government. (1998). Ministry of Education. Gaborone: Government Printer.

Chebanne, A. M. (2014). The lack of multilingual education in Botswana-Tragic consequences for Khoesan languages (Book Chapter). (In press)

Chebanne, A., \& Monaka, K. (2005, April 7). The !Xo language of Northern Kgalagadi: A socio-linguistic survey and languages dynamic issues (UB TROMSO Series).

Commeyras, M., \& Inyega, H. N. (2007). An integrative review of teaching reading in Kenyan primary schools. Reading Research Quarterly, 42(2), 258-281.

Cotacachi, M. (1997). Attitudes of teachers, children and parents towards bilingual intercultural education. In N. Hornberger (Ed.), Indigenous literacies in the Americas: Language planning from the bottom up. New York, N.Y.: Mouton de Gruyter. 
Cummins, J. (2009). Fundamental psycholinguistic and sociological principles underlying educational success for linguistic minority students. In T. Skutnabb-Kangas, R. Phillipson, A. Mohanty, \& M. Panda (Eds.), Social justice through multilingual education. Bristol, U.K.: Multilingual Matters.

Garcia, M. E. (2004). Rethinking bilingual education in Peru: Intercultural politics, state policy and indigenous rights. In A. Mejia, Bilingual education in South America. Clevedon: Multilingual Matters Ltd..

Gatsha, G. (2005). Multilingualism in Southern Africa education-sharing experiences. Position paper presented at The International Mother Language/Tongue Day Celebrations, Gaborone, Botswana.

Grenoble, L. A., \& Whaley, L. J. (2006). Saving languages: An introduction to language revitalization. Cambridge, U.K.: Cambridge University Press.

Haboud, M. (2009). Teaching foreign languages: A challenge to Ecuadorian bilingual intercultural education. International Journal of English Studies, 9(1), 63-80.

Halliday, J. A. (2014). Identity, voice and agency in ELL literacy development across grades. Presentation at The 64th Annual Literacy Conference, Marcos Island, Florida, U.S..

Hamel, R. E. (1994). Indigenous education in Latin America: Policies \& legal frameworks. In T. Skutnabb-Kangas, \& T. Phillipson (Eds.), Linguistic human rights: Overcoming linguistic discrimination. New York, N.Y.: Mouton de Gruyter.

Hays, J. (2002). Education and the San of Southern Africa: The search for alternatives. In N. Mazonde (Ed.), Minorities in the new millennium: Perspectives from Botswana (pp. 73-88). Gaborone: Light Books. Retrieved January 1, 2015, from http://www.unesco.org/most/In 2pol.htm

Julius, T. (2014). Home and school factors as determinants of achievement in reading comprehension among senior secondary school students in Ogun State Nigeria (Ph.D. dissertation, University of Botswana).

Kaare, B. (1994). The impact of modernization policies on the hunter-gatherer Hadzabe: The case of education \& language, policies of post-independence Tanzania. Oxford, U.K.: Berg Publishers.

Kembo, J. (2000). Language in education and language learning in Africa. In V. Webb, \& E. Kembo-Sure (Eds.), African voices: An introduction to the languages \& linguistics of Africa. Oxford, U.K.: Oxford University Press.

Ketsitlile, L. E. (2009). San junior secondary school understandings of literacy in school and at home: A case study (Doctoral dissertation, University of Georgia, USA).

Ketsitlile, L. E. (2011). The status of literacy education for the San of Botswana. AlterNative: An International Journal of Indigenous Peoples, 7(3). Retrieved from https://www.facebook.com/lone.ketsitlile.1

Ketsitlile, L. E. (2014). The missing link in San peoples formal education in Botswana: Culturally relevant pedagogy (Book Chapter). (In press)

Ketsitlile, L. E., Bulawa, P., \& Kgathi, O. T. (2013). Transforming literacy research for the San of Botswana: Adopting appropriate research methodologies. AlterNative: An International Journal of Indigenous Peoples, 9(1), 45-59.

Le Roux, W. (1999). Torn apart: San children as change agents in a process of acculturation (Commissioned by Kuru Development Trust and WIMSA).

Magogwe, J. (2007). An investigation into attitudes and motivation of Botswana secondary school students towards English, Setswana and indigenous languages. English World-Wide, 28(3), 311-328.

Mazonde, I. (2002). The San in Botswana and the issue of subjectivities-national disintegration or cultural diversity? In I. N. Mazonde (Ed.), Minorities in the millennium: Perspectives from Botswana (pp. 57-71). Gaborone: Light books.

Mihesuan, D. B., \& Wilson, C. A. (2004). Indigenizing the academia: Transforming scholarship and empowering communities. Lincoln, N.E.: University of Nebraska Press.

Mokibelo, E. B., \& Moumakwa, T. V. (2006). An investigation into reading texts in English by Khoe children: A case study of Motshelagatau primary school in the central district. Gaborone: University of Botswana.

Mooko, T. (2006). Countering the threat of language death: The case of minority languages in Botswana. Journal of Multilingual and Multicultural Development, 27(2), 109-125.

Mule, L. (1999). Indigenous languages in the school curriculum: What happened to Kiswahili in Kenya? In L. Semali, \& J. C. Kincheloe (Eds.), What is indigenous knowledge? Voices from the academy. New York, N.Y.: Falmer Press.

Muthwii, M. J (2004). A fresh quest for new language bearings in Africa. In M. J. Muthwii, \& A. N. Kioko (Eds.), New language bearings in Africa: A fresh quest. Clevedon, U.K.: Multilingual Matters.

National Commission on Education (NCE). (1977). Education for Kagisano. Gaborone: Government Printer.

NCE. (1993). Report of the National Commission on Education. Gaborone: Government Printer. 
Nyati-Ramahobo, L. (1991). Language planning and education policy in Botswana. Retrieved from http://repository.upenn.edu/ dissertations/AAI9125729

Nyati-Ramahobo, L. (1998). Language, culture and learning: The missing link in teacher education. In C. D. Yandila, P. Moanakwena, F. R. O'Mara, A. M. Kakanda, \& J. Mensah (Eds.), Improving education quality for effective learning: The teacher's dilemma. Gaborone: Ministry of Education.

Nyati-Ramahobo, L. (1999). The national language: A resource or a problem: The implementation of the language policy of Botswana. Gaborone: Pula Press.

Nyati-Ramahobo, L. (2002). From a phone call to the high court: Wayeyi visibility and the Kamanakao Association's campaign for linguistic and cultural rights in Botswana. JSTOR, 28(4), 686-709.

Nyati-Ramahobo, L. (2004). Language planning and policy in Africa. In B. Richard, Jr. Baldauf, \& R. B. Kaplan (Eds.), Language planning and policy in Africa (pp. 21-78). Clevedon, U.K.: Multilingual Matters Ltd..

Nyati-Ramahobo, L. (2005, June). Towards multicultural education for Khoesan peoples of Botswana: Breaking barriers, expanding opportunities and exploring possibilities. Paper presented at The Regional Mother Tongue Conference, Gaborone, Botswana.

Pridmore, P. (1995). Learning and schooling of Basarwa (Bushmen) children in Botswana. Prospects, XXV(4), 707-722.

Rantsudu, M. G. (2014). Universal human rights treaty mechanisms-An opportunity for realizing San self-determination as indigenous peoples of Botswana. In P. Skold, M. Bolaane, \& M. Sandstrom (Eds.), Parallel issues and mutual challenges for indigenous peoples and research-A collaboration between San Botswana and Swedish Sapmi. (In press)

Saugestad, S. (2004). The indigenous peoples of Southern Africa: An overview. In R. Hitchcock, \& D. Vinding (Eds.), Indigenous peoples' rights in Southern Africa (pp. 22-41). Copenhagen: IWGIA.

Semali, L., \& Kincheloe, L. (1999). Introduction: What is indigenous knowledge and why should we study it? In L. Semali, \& J. C. Kincheloe (Eds.), What is indigenous knowledge? Voices from the academy. New York, N.Y.: Falmer Press.

Skutnabb-Kangas, T., Phillipson, R., \& Rannut, M. (1994). Linguistic human rights: Overcoming linguistic discrimination. New York, N.Y.: Mouton de Gruyter.

Stroud, C. (2003). Postmodern perspectives on local languages: African mother tongue education in times of globalization. International Journal of Bilingual Education and Bilingualism, 6(1), 17-36.

Ukwuoma, C. U. (2014). College lecturer's perspectives on the role of Nigerian Creole in teacher education. Retrieved from http://gradworks.umi.com/35/80/3580948.html

United Nations Educational, Scientific, and Cultural Organization (UNESCO). (2014). EFA global monitoring report 2014: Teaching and learning. Paris: UNESCO.

Wagner, R. W. (2006). An endless desert walk: Perspectives of education from the San in Botswana. International Journal of Educational Development, 26(1), 88-97.

White-Kalauty, M. (2007). Reflections on native American reading: A seed, a tool, and a weapon. Journal of Adolescent \& Literacy, 50(7), 560-569.

Zips-Mairitsch, M. (2013). Lost lands?: (Land) Rights of the San in Botswana and the legal concept of indigeneity in Africa. Copenhagen: IWGIA. 